\title{
THE PROFESSIONAL AND ETHICAL POTENTIAL OF LITHUANIAN PROPERTY VALUERS
}

\author{
Birutė GALINIENĖ ${ }^{1}$, Albinas MARČINSKAS ${ }^{2}$ and Steponas DEVEIKIS ${ }^{3}$ \\ ${ }^{1}$ Department of Economic Policy, Vilnius University, Sauletekio al. 9, LT-10222 Vilnius, Lithuania \\ E-mail: Birute.Galiniene@ef.vu.lt \\ 2 Department of Business, Vilnius University, Sauletekio al. 9, LT-10222 Vilnius, Lithuania \\ E-mail: Albinas.Marcinskas@ef.vu.lt \\ ${ }^{3}$ Lithuanian Association of Property Valuers, K. Sirvydo g. 6, LT-01101 Vilnius, Lithuania \\ E-mail: ltva.lt@post.omnitel.net
}

Received 15 December 2004; accepted 11 February 2005

\begin{abstract}
Lithuania is a small developing market economy which inherited the specific soviet economic structure and so-called "homus sovieticus" mentality which excluded a possibility for business of property valuation. Within a historically short period of time Lithuania moved from the closed soviet economic area into the area of global economy, which presented different business valuation criteria. Taking the above into account, let us evaluate the professional and ethical potential of Lithuanian property valuers, who have played and will be playing a significant role in the country's economic development, and see whether this potential will enable them to become full-fledged members of the Western property valuers' community.
\end{abstract}

KEYWORDS: Property valuation; Valuers profession; Valuation system; Ethical potential

\section{SPECIFIC FEATURES OF THE DEVELOPMENT OF THE PROPERTY VALUER'S PROFESSION}

The history of property valuers activity in Lithuania is quite limited, and was ordered rather unexpectedly and unconsciously. What conditioned the development of property valuers of a certain structure and professional competence? While defining property valuation as a business it is necessary to note that the initial stage in market relations was stipulated by a specific growth of the entrepreneurship activity of the country's citizens. On the other hand, the country experienced unemployment as a socio - economic phenomenon, and what it means to have a profession which is in low demand. Such circumstances produced the social order for a new business activity - property valuation. Property valuation, as compared to other business types (first of all manufac- turing business), has several significant features. Property valuation had minimal or at least moderate investment requirements, and there were no major financial obstacles to engage in this activity. However, the complex nature of the property valuation procedure and the assumed responsibility called and still calls for quite high standards in intellectual abilities, personal features, life experience and connections (necessary for obtaining orders) of the potential property valuer. As the first decade of market economy proved, the risks related to financial recourses were not always adequately estimated. This should be applied in the understanding of the critical point in one's professional potential in property valuation. Part of property valuers a priori perceived property valuation as unsophisticated, believing that any kind of diploma of higher education ensures professional success of a future property valuer. Such view was also induced by the pro- 
fessional requirement set by the first property valuers - a qualification certificate. The qualification certificate cannot be compared to the specialized university studies - a long-standing professional requirement for property valuers' in the EU countries. In reality the professional development of property valuers as representatives of the professional activity had taken place prior to the transformation of university programs into specializations. Finally the qualification certificate was not a result of a broad fundamental education, but was based on narrow professional skills-oriented training.

Another important circumstance was determined by the novelty of the profession, which caused the absence of life experience based on real (positive and negative) situations. Both, the candidates to property valuers and those who assumed the right and responsibility to carry out their assessment could not critically and objectively estimate the benefits and shortcomings of the future professional activity. Therefore, as happens in similar situations, in the huge crowd of candidates (several times outnumbering the real demand for property valuers) there were various people: those cornered by hardships in life as well as unsophisticated optimists.

Undoubtedly there were some who associated the term "property" to favourable opportunities to accumulate personal property. This, as well as the significant decrease in living standards, equally stimulated the enthusiasm of all types of candidates. Part of the candidates most likely understood that property valuation, as a business does not have a characteristic marketing cycle: from an idea to mass production of a product. From this point-of-view, it is most important in property valuation to maintain the image of a trustworthy partner. We can pose a question, which had to be answered by future property valuers: "Is property valuation based on science or art?" Of course the importance of knowledge and technical skills cannot be minimized, but one cannot ignore the significance of self-presentation, ne- gotiation and communication skills in the business of property valuation. From the point of view of professional ethics, property valuers should endeavour to produce a defined psychological comfort to the clients (satisfaction by service) as a result of their professional activity.

In general the requirements for property valuers were not high. However when drafting the recent survey of property valuers the fact was taken into account that the concern about quality of some property valuers ends with the issue of a qualification certificate. A property valuer becomes full-fledged over a period of time, when he is protected from possible "professional injuries", or possibilities of lessons of unethical professional conduct. A property valuer should systematically develop an attitude that malpractice is punishable and ethical negligence is inadmissible.

However it is equally important to note the level of property valuers' customers. Part of the clients consisted of businessmen with criminal background. Such clients "knew" the value of the property they were interested in advance and all they sought was the corresponding report. This influenced the understanding among some property valuers that their activity was just a necessary technical document in an obscure chain of business.

On the other hand, it is necessary to note that state and private customers declare different interests; just as the state and so-called independent property valuers differently interpret methods of property valuation. This has influenced the mentality, culture, and professional ethics of Lithuanian property valuers.

Finally, the role of national business press should also be given attention. On the basis of content analysis of the business papers, the following conclusions could be drawn: 1) about 2 per cent of all publications address the problems of business ethics; 2) the relatively most important among these are the publications devoted to corruption and advertising; 3) subjects of confidentiality, deceit and lies share a relatively insignificant place among publications 
on business ethics; 4) most publications on business ethics avoid abstract theorizing and are oriented towards the prevention of particular phenomena.

However these conclusions embrace all types of business activity, only about 2 per cent of all publications are devoted to the service sector to which property valuation belongs. The national press does not address ethical problems arising in the activity of property valuation enterprises. However this does not create grounds for stating that property valuation enterprises meet the assumed ethical standards

\section{THE ESTABLISHMENT OF PROPERTY VALUATION SYSTEM IN LITHUANIA}

Two stages in the process of the establishment of property valuation system can be distinguished: the creation of property assessment methodology, most often used for privatisation purposes (1991 - 1995); and implementation of property valuation based on international standards in order to obtain recognition and to integrate into international labour division. The methodology of property assessment was created to implement the necessary policy of economic conversion without professional assistance from property valuers. This methodology was based on the legislation passed in 1991 - 1996, which sought to determine the procedure of property assessment and reassessment. The situation in this stage was hampered by the absence of information on free market, and the practice of property valuation at that time did not pursue international valuation standards.

A significant date in the establishment of property valuation system in Lithuania was 1994, when the Lithuanian Association of Property Valuers was founded [1]. The Association integrated into international structures, and published TEGOVOFA Guidance Notes on the Valuation of Fixed Assets, prepared by the European Association of Property Valuers (TEGOVOFA), Approved European Property
Valuation Standards (TEGOVA) and International Valuation Standards prepared by International Valuation Standards Committee [2, 4, 10].

In an attempt to overcome the difficulties of the transition period, in 1996 the Lithuanian Government by its resolution adopted property valuation methodology. The certification commission established in the same year approved property valuers qualification examination tests.

Although the uniform property valuation system was formally introduced already in 1996, it did not supersede administrative property assessment principles and did not eliminate the erratic element in the country's financial and economic systems.

The second stage of the establishment of property valuation system saw the creation of a multi-tier qualification scheme of property valuers (1998), evaluation and recognition of the European and American structural models of property valuers [3, 7, 8, 12, 13], and drafting of the law on Basics of Property and Business Valuation [11]. The four-tier qualification scheme of property valuers was introduced (both authors were the members of the working group), based on the concept of a possibly smooth transformation of the old "universal" system. In this way all who had temporary property vasluer's certificates became assistant valuers. The most numerous group of property valuers professional community - its backbone - was made up of valuers specialising in mass valuation. Senior valuers received the right to evaluate objects of state importance: significant, unique, and uncommon property objects. It was sought to protect such property from local incompetence. The fourth level of property valuers (expert valuers) is related to still developing system of professional arbitration.

The new multi-tier qualification scheme eliminated the universal nature of the property valuer and legitimated the specialization, which created favourable opportunities for the professional development of the national community of property valuers. 
However it would be a mistake to claim that the new system of property valuation is really modern and complies with the Western standards. Firstly, the principle of specialization in the reformed system of property valuation is not clearly defined. Secondly, the requirements for potential valuers present some sort of a compromise with the existing reality. Thirdly, monitoring of the property valuation business is assigned not to a professional body but to a state institution. Although, taking into account the level of maturity of professional organization of property valuers in Lithuania, the method of state monitoring is undoubtedly the best choice in the transition period.

In future the powers of the Lithuanian Association of Property Valuers should be strengthened and expanded. Today the Association embraces different basic professions (economists, civil and planning engineers, property managers, lawyers and other specialists working in private and state sectors and universities). In 2003 the number of certified valuers (real estate, movable property and business) exceeded one thousand (877 assistant valuers and 265 valuers). If to compare the proportion of property valuation specialists (valuers) per one million inhabitants in small European countries, the numbers will be as follows: Finland - 1346, Ireland - 916, Denmark - 585, Norway - 244, Lithuania - 144 [6, $8,9]$. The real situation in Lithuania is only reflected partially of course, it implies that the numbers of property valuers are likely to increase together the development of economy and processes of globalisation.

One of the main problems facing the Association is the implementation of Continuing Professional Development model (CPD) [5, 7]. It would allow to harmonize the education of property valuers with the international standards. In Lithuania CPD is seen as formal training courses, seminars or instructions, which can be attended in free of work time. Such somewhat wrong attitude towards CPD is still to be changed in Lithuania. On the other hand the prevailing "fragmentary attitude" towards
CPD (which stresses the importance of separate professional training sessions aimed at developing of certain skills) could be transformed into the "focused attitude", which focuses on the needs to learn and constantly upgrade one's professional qualification.

Taking into account the experience of foreign countries and seeking to upgrade the professional competence of Lithuanian property valuers to internationally recognized professional standards, the length of continuous professional development as expressed in hours per year should be as follows: assistant valuers - 50 hours, valuers -40 hours, senior valuers - 30 hours, experts -20 hours. The length of continuous professional development should be estimated from the moment a valuer obtains a qualification certificate of a certain level. In parallel the following certification regulation should come into effect: assistant valuers who do not seek a higher qualification certificate should be assessed every 3 years, valuers every 4 years, senior valuers and experts every 5 years. In this way, in Lithuania like in other Western countries, alongside the voluntary professional development system, the mandatory CPD system would be formed.

Undoubtedly it is important to evaluate the activity the Lithuanian property valuers are engaged in, which not only does characterize the market of valuation services, but defines the increasing professional potential of property valuers. Roughly, $54.7 \%$ of all valuations constitute real property valuations, $44.9 \%$ are valuations of movable property and $0.4 \%$ comprise business valuations. In several larger enterprises the proportion of income obtained from valuation business in the general revenue of a company $^{1}$ amounts to $13-15 \%$. In most companies this proportion constitutes 2 per cent or even less. This proves that there exists a clear differentiation of the analyzed enterprises, and the concentration of valuation services is obvious. The provision of valuation services is likely to

\footnotetext{
1 In 2003 there were 126 licenced property and business valuation enterprises in Lithuania.
} 
concentrate in several enterprises (including foreign companies). Apparently small companies with a wide range of activities will disappear.

\section{THE SURVEY OF THE COMPLIANCE OF LITHUANIAN PROPERTY VALUERS TO ETHICAL NORMS}

Such a subtle phenomenon as a survey of ethical capacity requires a complex methodology. From the very beginning the pilot survey rejected the application of dichotomy "yes-no". The position of the observer and "discussions" on the application of certain ethical norms in the survey has proved expedient. It is necessary to stress that the actual survey of property valuers (2003 November - December) was quite complicated. From the very beginning the respondents fell into three categories. The first (consisting of up to $25 \%$ of the respondents) maintained that the norms of the professional code are not questionable. The second category of respondents (about 40\%) agreed that there exist a contradiction between ethics and business. The rest demonstrated some kind of passive position or ignorance.

The survey proposed a premise that the mere choice of property valuation as a business activity quite significantly influences property valuers' attitude towards ethical norms. It should be noted that the respondents found it most difficult to evaluate their motives of choice, which resulted in quite a wide range of responses. A third of respondents out of 104 $(32.7 \%)$ claimed that the biggest advantage in property valuation was that it did not require big investments at the initial phase of the business, as compared to other fields of business activity. From other alternatives in the questionnaire, $7.7 \%$ of respondents chose "freedom to act without binding oneself to business ethics norms". A relatively small percentage of respondents (only $1.9 \%$ ) chose fairly big income as the advantage of property valuation. $46.2 \%$ of respondents answered the questions by providing individual answers rather than selecting an alternative from the questionnaire.
The most common response was the interesting nature of property valuation activity, creativity, and possibility to apply knowledge (nearly half of the respondents who provided individual answers chose the latter as an advantage). Independence (18\% of respondents) constituted a comparatively significant part of the answers. The latter motive, however, can be interpreted differently, but as the interviews showed, independence is associated with flexible working hours.

The respondents also presented quite personal motives (occupation till retirement, prestige of property valuation as business activity, etc.) At least one of the respondents noted a relatively small competition in the property valuation business.

Summarizing, it could be stated that morally based motives for the choice of business activity comprise the majority of all responses. Or the conclusion could be drawn that the value system of Lithuanian property valuers are favourable rather than unfavourable for the compliance with ethical standards.

A rather subtle question in every survey is the evaluation of professional competence. The researchers did not use a straightforward selfanalysis type of question asking for peer evaluation. Of course self-analysis and peer evaluation could be considered as two radical poles in the continuum. However we chose a likely more objective peer evaluation.

The survey revealed these more important issues. As became clear the national valuers are quite objective in evaluating their possibilities in the framework of the EU: $67.3 \%$ of respondents agree that as compared with the EU valers, their competence is not high enough, although it is sufficient for operation in the national market, i.e. they agree on both: the novelty of the profession in the Lithuanian market and the limitations of the assessed objects in the national property market. The fact that $26.4 \%$ of respondents agreed that they lack knowledge and skills to operate in the national market shows that property valuers are self-critical. At the same time they do not 
exceed the limit where the essential lack of competence could be discussed (the latter answer was chosen by one respondent). Thus it could be stated that the efforts of the Lithuanian Association of Property Valuers to invite experts in property valuation from the West to their seminars have entrenched the standards of professional ethics in the minds of national property valuators.

The existing Lithuanian property valuers' code stresses the importance of professional diligence. The survey asked to evaluate peers in a 10-point system. The respondents' answers fell into 4-10 points range, the average being 6.3 points. Can we say that the respondents were critical and objective in evaluating their colleagues' professional diligence? Of course a fixed point is not a strong argument in grounding the level of professional diligence of property valuers. But similar research will enable to identify trends and to find justification for certain changes in future.

It was quite complicated to obtain the answers to a quite delicate and at the same time confidential question on property valuers' fees. The standards of professional ethics unconditionally require that the property valuer's fee is not determined by the value of the object under evaluation. We tried to develop this subject (the dependence of the fees) by posing two questions. The first one asked whether there is any risk in discussing with the customer in advance the scope of work, costs and the fees (in a 10 point scale). In reality there exists a possibility of a mistake in the estimation of the scope and costs of work if a property valuer only tentatively familiarizes himself with the object (especially when the object is a complex one). The transaction based on the relation between the fee and the value of the object under evaluation, is less risky but unallowable by the norms of professional ethics.

The survey once again proved, that the opinion of respondents is also "average": the risk associated with the prior estimation of the scope of work, costs and fees was graded at 5.5 points. Statistically it could be claimed that this grade implies a tacit disapproval of the professional ethics norm.

The latter presumption is accentuated by the second question on the subject: what arguments could justify the statement that the fee could (should) depend on the object value? The obtained individual answers suggest that the bigger number of respondents $(51.9 \%)$ do not agree with the mentioned norm of the professional code. The most common argument justifying the dependence of the fee on the object value is the property valuer's responsibility. Other arguments are equally important: 1) the economic situation of the state often makes the object value and the fee incompatible; 2) the customer who knows the approximate value of an object agrees to pay a corresponding fee; 3) the higher value of an object entails more difficulties in defining its real value.

It is not necessary to argue or deny the respondents' opinion. It is important to evaluate two significant conclusions of the survey: 1) the existing property valuation business relations in Lithuanian are bound to violate the provisions of the professional code; 2) the system of values of some property valuers comes into conflict with the mentioned provision of the professional code.

A very similar situation exists in the argumentation about the possibility to obtain fees for mediating in the search of clients. The smaller part of respondents $(44.2 \%)$ answered that they do not have such arguments, or they know that such mediation is not permitted. The rest justify such mediation because: 1) mediation is also an element of a business; 2) every service should be remunerated for; 3) time is consumed; 4) there are no other options in Lithuania because of the limited market and lack of orders.

The results of the inquiry into professional assistance to peers found a much better mood. Only $10 \%$ of the respondents claim that their peers never asked for professional assistance. $48.1 \%$ said that their peers approached them several times, the rest $(40.4 \%)$ - that more than ten times. It somewhat breaks the ste- 
reotype that in Lithuanian culture it is not easy to overcome the barrier of professional assistance. Of course similar findings or discrepancies in the results of further analogous surveys will enable to draw more reliable conclusions.

From the point of view of professional ethics, the question of indiscreet treatment of the information that the property valuers obtain in the process of work was very important. About $50 \%$ of the respondents were diplomatic in denying that they possess such information. $13.5 \%$ were sure that they do not have information about such cases. Only about 2 per cent of the respondents think that such cases are quite common. $30.8 \%$ of the respondents think that their peers are indiscreet in treating the information they obtain in the course of their work. Indeed when we discuss such latent phenomenon as indiscreet treatment of information we should take into account the actual experience of a property valuer and facts that became public. In any case it could be assumed that in Lithuania there is a problem of indiscreet treatment of information that a property valuer obtains in fulfilment of his order.

The alternative answers to the question on the necessity to notify the customer about the noticed professional mistakes in one's work should also be presented and grounded. In an attempt to obtain the most direct opinion, the alternative answer that is also provided in the professional code ("necessary in any case") was presented as the third and last option. The first option contained the alternative that it is necessary to inform the customer because of possible problems which a mistake might cause to the property valuer. The second option con- tained an alternative that such notification is not necessary because the mistake cannot be corrected anyway. Most of the respondents $(85.7 \%)$ chose the third alternative as their answer - it is necessary to always notify the customer of all the noticed mistakes in one's work. The alternative "it is necessary in case that if the mistake is noticed it will cause problems" was chosen by $10.2 \%$. Therefore only an obvious minimum of respondents $(4.1 \%)$ disregards the ethical provision, because the final result or possible consequences do not change the situation.

The survey also included a question on application of penalties for violation of regulations of professional ethics to property valuers (types and scope of penalties). The obtained answers are summarized in Table 1.

As could be seen, the respondents accept the whole scope of the application of penalties. At the same time the differences in the necessity of application are obvious. This allows us to draw certain generalizations: 1) the fact of violation of the professional ethics of property valuers is obvious; 2) inadequate application of penalties for violations of professional ethics is obvious.

Therefore it is necessary to admit that the Lithuanian property valuers do not completely exhaust the possibilities of the ethical factor to increase their competitive capacity. Speaking about the strategy of the research of the professional ethics of property valuers it is necessary: 1) to ensure the continuity of the research; 2) to initiate similar research in other countries (the EU and former Soviet Union countries). Only on this condition it will be possible to develop a credible database, which

Table 1. Penalties for violation of ethical regulations and the scope of their application

\begin{tabular}{llll}
\hline \multirow{2}{*}{ Penalty } & Scope of application & & \\
\cline { 2 - 4 } & $\begin{array}{l}\text { applicable to nearly all } \\
\text { property valuers }\end{array}$ & $\begin{array}{l}\text { applicable occasionally, to } \\
\text { certain property valuers }\end{array}$ & $\begin{array}{l}\text { I don't see grounds for a } \\
\text { penalty in the given situation }\end{array}$ \\
\hline caution & 42,3 & 13,5 & 44,2 \\
note of warning & 26,9 & 30,8 & 42,3 \\
suspension of certificate & 13,5 & 34,6 & 51,9 \\
abatement of the certificate & 5,8 & 13,5 & 80,7 \\
\hline
\end{tabular}


would allow us to form a more flexible policy on the ethical education of property valuers.

\section{CONCLUSIONS}

We have sketched the professional and ethical potential of a developing community of property valuers in a small post-soviet country. Naturally this potential will be developing more dynamically under the growing influence of external factors. However it is equally important for property valuers of different countries to observe the dynamics of their professional and especially ethical potential to duly improve the adopted professional development strategies. It is very important for property valuers of post-soviet countries to see and to realistically evaluate the context of their potential. Obviously the continuity of the instituted research should be ensured in Lithuania, but it is more important (and that is the aim of this article) to instigate similar research in other countries.

\section{REFERENCES}

[1] A. Aleksienè, Lithuanian association of property valuers: the years of creating and acting, Vilnius: LTVA, 2000. (In Lithuanian).

[2] Approved European Property Valuation Standard, London: Estate Gazette, 2003.
[3] R. M. Betts, Real estate appraisal, California, 1991.

[4] P. Champness, Approved European Property valuation Standard, London, Estates Gazette, 1997.

[5] Continuing Professional Development, FIG Publication No. 15, September, London, 1996.

[6] European Council of Real Estate Professions (CEPI), Annual Report 2001, 2003.

[7] B. Galiniené, The Quality of Property Valuer Investment for Evolution and Success, International Journal of Strategic Property Management, 7(2), 2003, p. 84-95.

[8] B. Galinienè, The System of Business and Property Valuation. Formation and development concept, Vilnius, Lithuania, 2004, 307 p. (In Lithuanian).

[9] B. Galinienè, A. Marčinskas, The Wealth of Lithuania: its Value and its Assessors, Ekonomika, 54, 2001, p. 37-43. (In Lithuanian).

[10] International Valuation Standard, Sixth edition, London: International Valuation Standards Committee, 2003.

[11] Law on fundamentals of valuation of property and business of the Republic of Lithuania, Žin., 1999, Nr. 52-1672. (In Lithuanian).

[12] State Powers in the Real Estate Evaluation, Warsaw, Poland, 1996. (In Polish).

[13] The Royal Institution of Chartered Surveyors, Guide and Rules to Assessment of professional Competence, General Practice, London, 1991.

\section{SANTRAUKA}

\section{LIETUVOS TURTO VERTINTOJŲ PROFESINIS ETINIS POTENCIALAS}

Birutė GALINIENĖ, Albinas MARČINSKAS, Steponas DEVEIKIS

Aptariamos naujos ekonominès plètros galimybès Europos Sajungos ekonominëje erdvèje ir Lietuvos turto ir verslo vertinimo sistemos lygis, sistemos plètros etapų derinimo principai ir problemos, vykdomų jos reformų efektyvumas ir padariniai. Išryškinti turto vertintojų profesijos formavimosi Lietuvoje, palyginti su užsienio šalimis, specifiniai bruožai, atskleista daugiapakopès turto vertintojų kvalifikacijos sistemos esmè. Pateiktas Lietuvos turtą ir verslą vertinančių įmonių spektras, jų veiklos charakteristika bei vertintojų profesinès brandos ịvertinimas. Pabrèžtas visuomeninių profesinių organizacijų vaidmuo ir tarptautinis bendradarbiavimas turto vertinimo srityje. Svarbi vieta straipsnyje skirta Lietuvos turto vertintojų etiniam potencialui ịvardyti, apklausos rezultatų analizei. Remiantis Lietuvos turto vertintojų etiškumo tyrimais, atskleistos jų konkurencingumo didinimo etiniu pagrindu galimybės. 